Dear Sir:

Congratulations to Norman D. Stevens and his colleagues at the Wilbur Cross Library, University of Connecticut, for their excellent approach to a sensible professional work week. Their example should be followed by all college and university librarians. I assume that Dr. Stevens and his colleagues are expected to devote a considerable amount of additional time beyond thirty-five hours to activities that provide professional growth and development. They should consider it a part of their responsibility as members of an academic community.

Sincerely,

J. Carlyle Parker

Head of Public Services and

Assistant Librarian

Stanislaus State College

Turlock, California

\title{
Annual Conference Meetings
}

Annual Conference

Dallas, Texas

June 20-26, 1971

The following schedules are tentative. A final schedule, with locations, will be mailed by Mary Cilluffo, Assistant for Conference Arrangements, to officers and chairmen of all ALA groups. Each chairman should notify his committee.

\section{ACRL Preconferences}

Rare Books Section

June 17-19, 1971, University of Texas, Austin

"The Interdependence of Rare Books and Manuscripts."

UNIVERSITY LiBRaRIES SECTION June 18-19, 1971, Dallas, Texas

"Librarians Confront the New Undergraduate Environment."

\section{Confenence Phograms}

\section{LED/ACRL Program}

Wednesday, June 23, 2:00-4:00 p.m.

Chairman: Sister M. Laurette McCusker, Rosary College, River Forest, Ill.

"Implications of Government Legislation for Libraries."

Committee on Cooperation with Educational and Professional Organizations

Tuesday, June 22, 12:30 p.m.-Luncheon

Chairman: James F. Govan, Swarthmore College, Swarthmore, Penn.

\section{College Library Section}

Tuesday, June 22, 4:30-6:00 p.m.

Panel discussion on Proposed Guidelines for College Libraries.

Moderator: Norman E. Tanis, San Fernando Valley State College, Northridge, Calif.

Panelists: Stanley McElderry, Graduate School of Library Science, University of Texas, Austin. (Additional panelists to be announced.)

Junior College Library Section June 22, 2:00-4:00 p.m.
"Accountability for Learning Resource Centers."

Speakers: Dr. Tom Hatfield, Texas College and University System, Austin; Dr. Richard Banister, San Diego Community Colleges, San Diego, Calif.

Rare Books Section, ACRL

Monday, June 21, 9:00-10:30 a.m., Bridwell Library, Southern Methodist University, Dallas, Texas.

"The Present Status of Training Special Collections Librarians in Library Schools and Recommendations for the Future."

Moderator: Leslie W. Dunlap, University of Iowa Library School, Iowa City.

Speakers: Richard Ploch, University of Arizona, Tucson; and John Swingle, Alta California Bookshop, Albany.

11:00-12:00 noon, tour of DeGolyer Collection, Southern Methodist University campus

Subject Specialists Section and Agricultural and Biological Sciences Subsection Wednesday, June 23, 4:30-6:00 p.m.

"Subject Specialists in Academic Libraries." "The Impact of the Subject Specialist on Academic Library Organization."

Speaker: Eldred Smith, University of California, Berkeley.

"Academic Library Services and the Subject Specialist."

Speaker: Alan Taylor, Indiana University, Bloomington.

"The Role of Subject Specialists in Undergraduate Colleges."

Speaker: Thomas Kirk, Earlham College, Richmond, Ind.

Panel discussion: Joseph C. Shipman, moderator.

SSS/Agricultural and Biological Sciences Subsection. (See Subject Specialists Section)

SSS/Art Subsection

Monday, June 21, 9:30 a.m.-5:00 p.m.

Tour: "Art Library Collection Building for Community Education." (For details and res- 
ervation information see CRL News, April, p.102.)

Tuesday, June 22, 4:15-6:00 p.m.

Visit to Fine Arts Center, Southern Methodist University.

Informal reception, 4:15-5:00 p.m.

Speaker: 5:00-6:00 p.m.: Prof. Roy E. Graham, University of Texas, Austin.

"Preservation of our Cultural Heritage" (with emphasis on the role of the art library in documentation of that heritage).

\section{SSS/Asian and North African Subsection} Friday, June 25, 2:00-4:00 p.m.

Program theme: the area collection, its raison d'etre and unique values; its effective organization and administration, internally and vis-à-vis the main library.

Speakers: Charles R. Bryant, Yale University Library, New Haven, Conn.; Henry Scholberg, Ames Library of South Asia, University of Minnesota, Minneapolis; Weiying Wan, Asian Library, University of Michigan.

SSS/Education and Behavioral Science Subsection

Thursday, June 24, 4:30-6:00 p.m.

Panel to discuss Implication of National Council for the Accreditation of Teacher Education.

Law and Political Science Subsection of THE ACRL

Wednesday, June 23, 2:00-4:00 p.m.

Speakers: James R. Craig, Southern Methodist University, "Tax Exempt Status of NonProfit Organizations (Library Associations)"; Dr. Frank G. Burk, National Archives and Records Service, "The Impact of Subject Specialists in Presidential Libraries."

ACRL University Libraries Section

Monday, June 21, 4:30-6:00 p.m.

"Criteria for Excellence: Progress Report of the ARL-ACRL Joint Committee on University Library Standards."

Speaker: Robert B. Downs, University of Illinois, Urbana.

\section{Business Meetings}

ACRL MEMBERSHIP

Thursday, 2:00-4:00 p.m.

ACRL Board of Directors

Monday, June 21, 8:30-10:30 p.m.

Thursday, June 24, 8:30-10:30 p.m.

\section{ACRL CoMmitTeES}

Audio-Visual Committee

Sunday, June 20, 4:30-6:00 p.m.

Wednesday, June 23, 12:00-2:00 p.m.

Committee on Academic Status

Monday, June 21, 2:00-4:00 p.m.

Wednesday, June 23, 4:30-6:00 p.m.
Committee on Cooperation with Educational and Professional Organizations

Tuesday, June 22, 12:30-luncheon

Committee to Revise the ACRL Constitution and Bylaws

Tuesday, June 22, 2:00-4:00 p.m.

Committee on Standards and Accreditation Monday, June 21, 10:00-12:00 noon

Wednesday, June 23, 4:30-6:00 p.m.

Committee for the Revision of the ALA Standards for College Libraries

Monday, June 21, 4:30-6:00 p.m.

Subcommittee on the Revision of the Junior

College Library Standards

Monday, June 21, 2:00-4:00 p.m.

Community Use of Academic Libraries

Tuesday, June 22, 4:30-6:00 p.m.

Chicago Conference Planning Committee

Wednesday, 4:30-6:00 p.m.

Planning Committee

Sunday, 10:00-6:00 p.m.

Wednesday, 2:00-4:00 p.m.

Publications Committee

Tuesday, June 22, 4:30-6:00 p.m.

Task Force for Recruitment of Minority Groups Monday, June 21, 10:00-12:00 noon

\section{ACRL Joint Committees}

AAJC-ALA Joint Committee on Junior College Libraries

Wednesday, June 23, 12:00-6:00 p.m.

NUEA-ACRL/ULS Joint Committee on University Extension Library Services

Wednesday, June 23, 2:00-4:00 p.m.

\section{Publications Committees}

\section{CHOICE, ACRL}

Monday, June 21, 10:00 a.m.

College and Research Libraries. To be scheduled.

Monographs Series. To be scheduled.

\section{Sections and Subsections}

\section{College Libraries Section}

Steering Committee

Tuesday, June 22, 2:00-4:00 p.m.

Committee on Non-Western Resources Thursday, June 24, 4:30-6:00 p.m.

Junior College Libraries Section

Executive Committee

Thursday, June 24, 4:30-6:00 p.m

Bibliography Committee

Tuesday, June 22, 4:30-6:00 p.m.

Communications Committee

Tuesday, June 22, 4:30-6:00 p.m.

Instruction and Use Committee

Wednesday, June 23, 2:00-6:00 p.m.

Rane Books Section

Executive Committee

Tuesday, June 22, 2:00-4:00 p.m.

Ad Hoc Committee on Manuscript Collections

Monday, June 21, 2:00-4:00 p.m. 


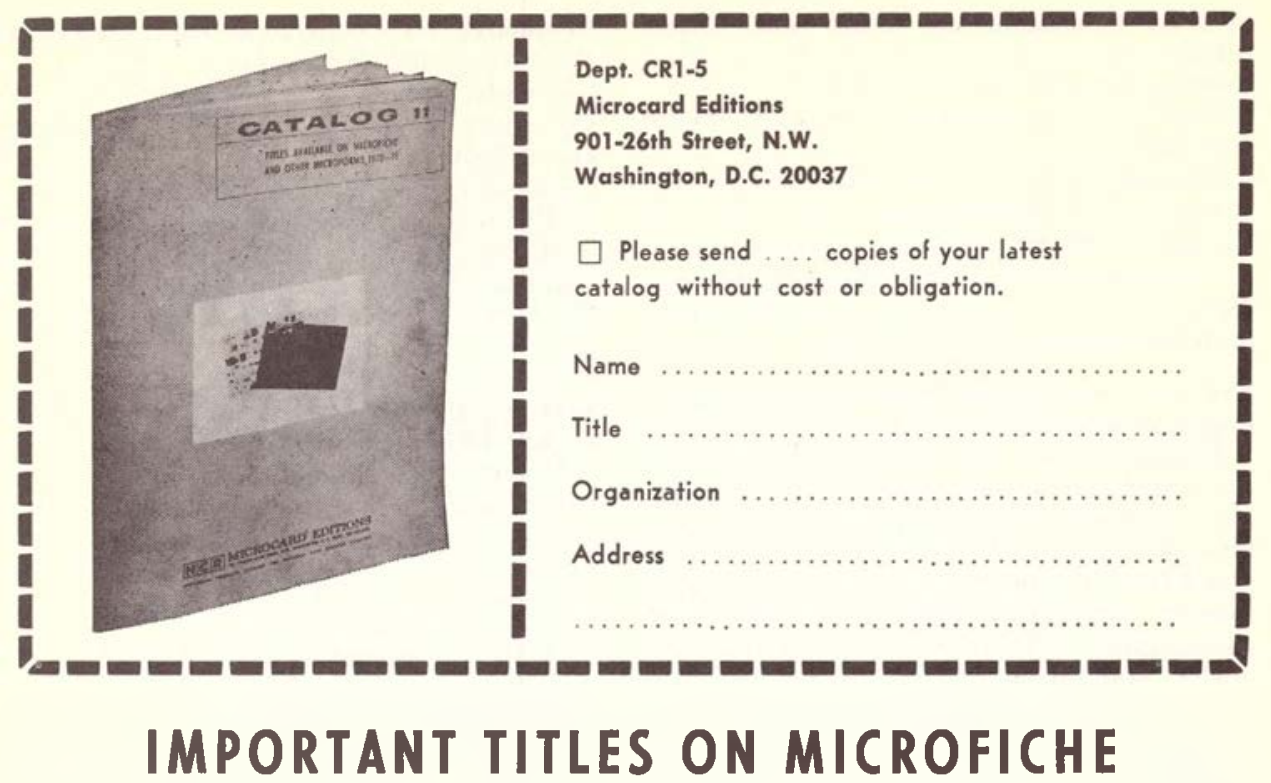

AINSWORTH'S MAGAZINE. Vols. I-26 (1842-54)

$\$ 90.00$

AMERICAN HISTORICAL REVIEW. Vols I-73 (1895/96-1967/68)

$\$ 450.00$

Arnold, Matthew. WORKS. London, 1903-04. I5 Vols. [BCL, p. 663] ... \$50.00 BOOKS FOR COLLEGE LIBRARIES (BCL-6). Selected titles from the "Education" chapter. Send for a list of titles

FILM QUARTERLY. Vols. I-22 (1945-68/69)

$\$ 72.00$

Guizot, Francois Pierre Guillaume, ed. COLLECTION DES MEMOIRES RELATIFS A L'HISTOIRE DE FRANCE, DEPVIS LA FOUNDATION DE LA MONARCHIE FRANCAISE JUSQU'AU I3e SIĖCLE. PARIS, |823-25. 3 | Vols. [BCL, p. 125]

Hakluyt, Richard. THE PRINCIPAL NAVIGATIONS, VOYAGES, TRAFFIQUES AND DISCOVERIES OF THE ENGLISH NATION. Glasgow, MacLeHose, 1903-05. I 2 Vols. [BCL, p. 263]

ILLUSTRATED LONDON NEWS. Vols. I-I45 (1842-19/4) (35mm microfilm) \$2100.00 MOTOR TREND MAGAZINE. Vols. I2-21 (1960-69)

NATIONAL UNION CATALOG. A cumulative author list representing Library of Congress printed cards and titles reported by other American Libraries, 1963-67. Ann Arbor, 1969. 72 Vols.

NEW YORK REVIEW OF BOOKS. Vols. I-I5 (1963-7I) [available on both microfiche and microfilm]

Ruskin, John. WORKS. N.Y., Longmans, Green, 1903-12. 39 Vols. [BCL, p. 678] 
Subject Specialists Section

Executive Committee

Thursday, June 24, 2:00-4:00 p.m.

Aht Subsection

Executive Committee

Thursday, June 24, 4:30 -6:00 p.m.

Business Membership

Wednesday, June 23, 2:00-4:00 p.m.

Asian and North African

Executive Committee

Thursday, June 24, 2:00-4:00 p.m.

Education and Behavioral Science SubsecTION

Executive Committee. To be scheduled.
Law and Political Science Subsection

Executive Committee

Thursday, June 24, 4:30-6:00 p.m.

Slavic and East European Subsection

Executive Committee. To be scheduled.

University Lihhahies Section

Steering Committee

Monday, June 21, 8:00 a.m.

Urban University Library Committee/PLA,

Metropolitan Area Library Service Committee

Wednesday, June 23, 4:30-6:00 p.m.

\section{From Inside the DLP}

\section{Dr. Katherine M. Stokes}

College and University Library Specialist, Training and Resources Branch, Division of Library Programs, Bureau of Libraries and Ed. ucational Technology, U.S. Office of Education, Washington, D.C. 20202.

Since the authorization for Title II-A of the Higher Education Act of 1965 will end June 30,1971 , you may want to keep yourself informed by asking your Congressman for copies of bills introduced to extend it. On January 22 Congressman Perkins of Kentucky introduced a bill to be cited as the Comprehensive Higher Education Act of 1971, H. R. 32. Senator Pell introduced a similar bill, S. 659, on February 8; Congressman Quie of Minnesota introduced on March 1 the Higher Education Opportunity Act of 1971, H. R. 5191. You may be interested in reading his remarks for March 1 in the Congressional Record beginning on page 1,041 .

This is a good time to consider what has been accomplished in the past five years with the Title II-A appropriations totalling $\$ 94,816$,000 . Statistically, we know that the number of libraries benefitted by the grants has risen from 1,830 in 1966 to 2,201 in 1970 . We know too that the enrollment in the institutions receiving grants totalled 5,169,638 in 1967 and had risen to a total of $7,023,118$ in 1970 , although there was a $\$ 25$ million appropriation for grants in 1967 and only $\$ 9,816,000$ in 1970 . The percentages of funds awarded to junior colleges in 1967 was 20.1 , and by 1970 , it was 30.597. Four-year colleges received 44.5 percent of the funds in 1967, but in 1970, their percentage had slipped to 39.422 . Universities also received a smaller percentage of the funds in 1970 , the 1967 amount being 35.4 percent and the 1970 figure 29.882. The remaining .99 percent in 1970 went to one-year institutions, usually technical institutes.

The narrative reports accompanying the statistical ones in the three years when special purpose grants were awarded, 1967 through 1969 , are occasionally accounts of very unusual or significant acquisitions, but in general, they fit an almost universal description of the situation of higher education institution libraries in the late $60 \mathrm{~s}$ in the U.S. Growing enrollments, rising book prices, and expanding programs at every level from undergraduate courses to the $\mathrm{Ph} . \mathrm{D}$. are characteristic reasons given for basic and background purchases made with federal grant money in most accounts of the use of basic, supplemental, or Special Purpose Type A funds. The type of purchase most frequently mentioned was backruns of scholarly journals in microform.

The Special Purpose Type B grants were awarded in many cases to university libraries which had been participating in the Farmington Plan. Accounts of their use largely concerned acquisitions of foreign publications to be shared by researchers on and off campus.

The Special Purpose Type C grants to consortiums of libraries showed more variation. They also paved the way for what is likely to be the direction in which academic libraries will be forced to aim their future activities because of their inability to obtain funds from private or public sources to continue to expand their individual collections indefinitely. The best summation of the long-range benefits of Type $\mathrm{C}$ grants is the following from a West Coast library's report:

"The availability of those funds has made it possible to strengthen our resources for graduate study and research without depleting our regu- 